\title{
Evaluation of Turmeric (Curcuma longa L.) Genotypes for Growth, Yield and Quality Traits under Northern Plains of India
}

\author{
Rohit Maurya ${ }^{*}$, V.P. Pandey ${ }^{2}$, Sandeep Yadav ${ }^{3}$, \\ Shubham Yadav ${ }^{4}$ and Rahul Kumar Verma ${ }^{5}$
}

\author{
${ }^{I}$ Department of Vegetable Science, College of Horticulture and Forestry, NDUA\&T, \\ Kumarganj, Faizabad - 224229, India \\ ${ }^{2}$ College of Horticulture and Forestry, NDUA\&T, Kumarganj, Faizabad-224229, India \\ ${ }^{3}$ Department of Vegetable Science, College of Agriculture, G.B.P.U.A \& T, \\ Pantnagar-263145, India \\ ${ }^{4}$ Department of Horticulture, R.M.L. Awadh University, Faizabad - 224001, India \\ ${ }^{5}$ Subject Matter Specialist (Horticulture), Krishi Vigyan Kendra, \\ Halsi, Lakhisarai, Bihar, India \\ *Corresponding author
}

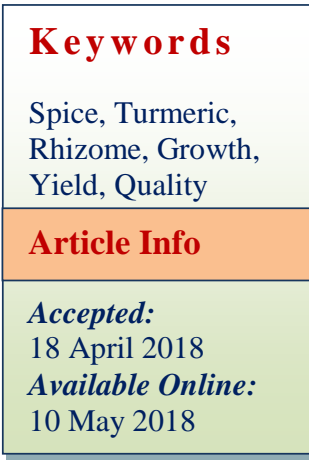

\section{A B S T R A C T}

The present experiment was conducted in randomized block design with three replications in summer season 2016-17 at the Main Experiment Station of the Department of Vegetable Science, NDUA\&T, Kumarganj, Faizabad. Total 22 genotypes were taken for study including two checks. Observations were recorded on various growth, yield and quality traits viz. plant height $(\mathrm{cm})$, number of tillers per clump, number of leaves per shoot, weight of fresh rhizomes per plant $(\mathrm{g})$, weight of mother rhizomes $(\mathrm{g})$, number of primary rhizomes per plant, weight of primary rhizomes per plant $(\mathrm{g})$, number of secondary rhizomes per plant, number of tertiary rhizomes per plant, rhizomes yield (q/ha), dry matter (\%), TSS, curcumin and oleoresin content. The data were analyzed as per statistical procedure. A wide range of variation was observed for all the characters under study. The most desirable genotypes for characters other than rhizome yield were NDH-67 for plant height and number of tillers per clump, NDH-68 for number of leaves per shoots and weight of primary rhizome, NDH-162 for weight of fresh rhizome, NDH-79 for weight of mother rhizome and number of primary rhizomes per plant, NDH-68 for weight of primary rhizome, NDH-74 for number of secondary rhizome and NDH-128 for tertiary rhizomes per plant. The three genotypes NDH-79 (348.50 q/ha), NDH-128 (345.80 q/ha) and NDH-74 (334.80 q/ha) produced significantly more rhizome yield than the best check Narendra Haldi-1 (310 q/ha). Thus, these genotypes may be recommended for commercial cultivation under northern plains of India. They can be further evaluated to identify best genotypes suitable for cultivation at other locations and further used in breeding programmes. 


\section{Introduction}

India, has always been known as land of spices, where 63 kinds of spices are grown is the largest producer, consumer and exporter of spices in the world (Pruthi, 1998). Curcuma longa L. Syn. C. domestica, commonly known as turmeric, in Sanskrit 'Haridra' in Hindi 'Haldi' is one of the most important spices crop. It is the third important spice crop of India, next to chilies and black pepper. The genus Curcuma longa $\mathrm{L}$. is considered to be a triploid with a somatic chromosome number of $63(2 n=3 x=63)$ belonging to the family Zingiberaceae considered to have originated in the slopes of hills in the tropical forests of west coast of South India. In India, the area, production and productivity of turmeric was 2.33 lakh hectare, 11.90 MT and 5.1 MT per hectare, respectively (Anonymous, 2014).

Turmeric is a tropical crop and needs a warm and humid climate with an optimum temperature of 20 to $30^{\circ} \mathrm{C}$ for normal growth and satisfactory production. It thrives best on sandy loam or alluvial, loose, friable and fertile soil rich in organic matter status and having a $\mathrm{pH}$ range of 5.0 to 7.5. Alkaline soil is not suitable for its cultivation. The crop cannot withstand water logging. It grows at all places ranging from sea level to an altitude of $1200 \mathrm{~m}$ above mean sea level. As a rainfed crop turmeric needs a well distributed annual rainfall of 250 to $400 \mathrm{~cm}$ for successful production. It is grown for underground stem called as rhizomes, which are used to impart flavor and colour to foodstuffs after clearing, drying, polishing and powdering. The rhizome contains yellow colouring component curcumin (3-9\%), essential oil (5-9\%) and oleoresin $(3-13 \%)$. Curcumin is gaining more importance in food industries, pharmaceuticals, preservatives and cosmetics. The ban on artificial colour has prompted the use of curcumin as a food colourant. In pharmaceuticals it is valued for the anti- cancerous, anti-inflammatory, antiseptic, antimicrobial and antiproliferative activities (Srimal, 1997). Turmeric oleoresin is used in brine pickles and to some extent in nonalcoholic beverages, gelatins butter and cheese etc. Curcumin also protects the liver from toxic compound. It acts as anticoagulant by inhibiting collagen and adrenaline induced platelet aggregation (Srivastava et al., 1985). It possesses wound healing properties and has antifungal effects. Antiviral properties in curcumin have been found to be effective against HIV (Srimal, 1993). Curcumin has anticancerous effects and has potential in the treatment of various forms of cancer, including prostate, skin and colon (Rao et al., 1995). Turmeric is most important to growers, consumers and industries, there is pressing need to increase its productivity and quality to fulfill the increasing demands throughout nation and abroad. Genetic improvement may play a vital role in increasing production and productivity. Performance of any crop depends upon its genetic makeup and climatic conditions of the region under which they are grown. Genotype which performs better in one region may not perform well in other regions due to varying climatic conditions. Hence, it is essential to collect and evaluate genotypes in order to select best genotype for a particular agro-climatic condition. Keeping in view the above fact the present investigation was carried out to find a suitable genotype for northern plains of India.

\section{Materials and Methods}

Twenty-two genotypes of turmeric were grown in randomized block design (RBD) with three replications at Main Experiment Station of the Department of Vegetable Science, Narendra Dev University of Agriculture and Technology (Narendra Nagar), Kumarganj, Faizabad during summer season 2016-17. Geographically the experimental site falls under humid 
subtropical climate and is located at $26.47^{\circ} \mathrm{N}$ latitude and $82.12^{\circ} \mathrm{E}$ longitude at an altitude of $113 \mathrm{~m}$ above mean sea level. The experimental field had sandy loam soil and slightly alkaline ( $\mathrm{pH}$ 8.0) in nature. The climate of experimental site is semi-arid with hot summer and cool winter. Healthy and treated rhizomes having 2-3 buds were planted at $30 \mathrm{~cm}$ apart in rows keeping $25 \mathrm{~cm}$ plant to plant distance. All the recommended package of practices was followed to raise a good crop. Five plants in each replication of each genotypes were selected and tagged to record observations on ten quantitative characters i.e., plant height $(\mathrm{cm})$, number of tillers per clump, number of leaves per shoot, weight of fresh rhizomes per plant $(\mathrm{g})$, weight of mother rhizomes (g), number of primary rhizomes per plant, weight of primary rhizomes per plant (g), number of secondary rhizomes per plant, number of tertiary rhizomes per plant, rhizomes yield (q/ha) and four qualitative characters namely dry matter (\%), TSS, curcumin and oleoresin content. The mean values were subjected to statistical analysis of data for each character as per method given by Panse and Shukhatme (1985).

\section{Results and Discussion}

A very wide range of variation in mean performance of genotypes was observed for all the characters under study. The genotypes showing high mean performance in desirable direction for various characters may be used as donors for improving the characters for which they had high mean performance. The mean performance of the genotypes with respect to all fourteen characters presented in Table 1.

The plant height varied from 54.83 to 120.70 $\mathrm{cm}$ with general mean of $83.29 \mathrm{~cm}$. None of genotype was found significantly superior than best check Narendra-Haldi-2 (120.70 $\mathrm{cm})$. The highest number of tiller per clump was produced by NDH-68 (3.85) followed by NDH-162 (3.80) while the lowest value resulted from CL-34 (1.733); the genotype, NDH-68 and NDH-162 were found significantly superior than both checks. The number of leaves per plant varied from 8.43 (NDH-74) to 23.50 (NDH-162); the genotype NDH-162 (23.50) had significantly more leaves than both check. In respect of growth attributes, the present finding show agreement with finding of Hegde et al., (1997) and Prasath et al., (2016).

The maximum weight of fresh rhizome $(\mathrm{g})$ per plant ranged from NDH-79 (260.22) to CL-54 (121.33) with general mean, 193.16; the Genotype NDH-79 (260.22) was found significantly superior than both checks. The maximum weight of mother rhizome was produced by NDH-79 (43.50 g) while the lowest value was resulted by NDH-16 (19.92); eight genotypes viz. NDH-161 (34.86), NDH162 (34.95), NDH-11 (34.80), NDH-68 (42.17), NDH-74 (35.55), NDH-79 (43.50), CL-34 (34.70), and RH-410 (34.76) were found significantly superior than both check.

The genotype CL-54 (2.97) recorded minimum number of primary rhizome per plant while it was maximum in NDH-68 (9.43); six genotypes viz. NDH-74 (9.20), NDH-68 (9.43), NDH-40 (9.05), NDH-128 (8.97), NDH-11 (8.60), and NDH-116 (8.20) had significantly more number of primary rhizome than both checks.

The maximum weight of primary rhizome per plant was observed in NDH-74 (131.00) while minimum weight of primary rhizome was observed in CL-54 (43.77) with general mean value was 91.02. Although six genotypes, NDH- 40 (115.67), NDH-74 (131.00), NDH128 (106.67), CL-52 (99.83), RH-406 (110.33) and RH-410 (101.33) were greater than general mean population but no genotype found significantly superior than either check. 
Table.1 Mean value of different genotypes for various characters

\begin{tabular}{|c|c|c|c|c|c|c|c|c|c|c|c|c|c|c|c|}
\hline $\begin{array}{l}\text { S. } \\
\text { No. }\end{array}$ & Genotypes & $\begin{array}{l}\text { Plant } \\
\text { height } \\
(\mathrm{cm})\end{array}$ & $\begin{array}{l}\text { Tillers } \\
\text { per } \\
\text { clump }\end{array}$ & $\begin{array}{c}\text { Leaves/ } \\
\text { plant }\end{array}$ & $\begin{array}{c}\text { Weight } \\
\text { of fresh } \\
\text { rhizome/ } \\
\text { plant }(\mathrm{g})\end{array}$ & $\begin{array}{l}\text { Weight of } \\
\text { mother } \\
\text { rhizome (g) }\end{array}$ & $\begin{array}{c}\text { Primary } \\
\text { rhizomes/ } \\
\text { plant }\end{array}$ & $\begin{array}{l}\text { Weight of } \\
\text { primary } \\
\text { rhizomes/ } \\
\text { plant (g) }\end{array}$ & $\begin{array}{c}\text { Secondary } \\
\text { rhizomes/ } \\
\text { plant }\end{array}$ & $\begin{array}{c}\text { Tertiary } \\
\text { rhizomes/ } \\
\text { plant }\end{array}$ & $\begin{array}{l}\text { Rhizome } \\
\text { yield } \\
\text { (q/ha) }\end{array}$ & $\begin{array}{c}\text { Dry } \\
\text { matter } \\
\%\end{array}$ & T.S.S. & Curcumine & Oleoresin \\
\hline 1 & NDH-161 & 91.30 & 2.27 & 18.40 & 199.33 & 34.33 & 5.00 & 72.83 & 4.13 & 3.03 & 292.27 & 20.80 & 8.20 & 4.30 & 9.55 \\
\hline 2 & NDH-162 & 90.70 & 3.67 & 20.07 & 205.33 & 32.50 & 4.87 & 75.57 & 3.53 & 2.73 & 297.72 & 21.40 & 7.20 & 4.13 & 9.20 \\
\hline 3 & NDH-11 & 91.57 & 2.20 & 13.82 & 206.33 & 32.33 & 8.60 & 97.43 & 10.70 & 3.10 & 298.94 & 22.00 & 7.20 & 3.20 & 6.45 \\
\hline 4 & NDH-16 & 93.79 & 1.97 & 15.40 & 186.17 & 19.92 & 4.73 & 55.00 & 11.20 & 5.13 & 246.16 & 20.87 & 7.37 & 3.75 & 7.25 \\
\hline 5 & NDH-40 & 88.33 & 2.73 & 13.00 & 200.88 & 24.00 & 9.05 & 115.67 & 5.07 & 2.30 & 296.12 & 22.77 & 8.20 & 4.25 & 9.22 \\
\hline 6 & NDH-68 & 107.57 & 3.20 & 11.93 & 199.77 & 42.17 & 9.43 & 84.33 & 15.33 & 2.80 & 299.88 & 24.77 & 8.30 & 3.16 & 6.57 \\
\hline 7 & NDH-74 & 91.57 & 2.20 & 8.43 & 232.07 & 33.55 & 9.20 & 131.00 & 13.66 & 6.77 & 334.80 & 22.87 & 4.30 & 4.15 & 9.88 \\
\hline 8 & NDH-79 & 59.88 & 2.53 & 8.73 & 252.22 & 43.50 & 4.40 & 89.58 & 16.43 & 6.23 & 348.50 & 20.90 & 6.40 & 5.18 & 9.65 \\
\hline 9 & NDH-115 & 71.60 & 2.20 & 8.60 & 178.17 & 30.62 & 4.80 & 58.28 & 11.72 & 4.52 & 258.77 & 22.50 & 8.10 & 3.27 & 6.75 \\
\hline 10 & NDH-116 & 65.06 & 2.47 & 11.83 & 142.73 & 20.40 & 7.20 & 60.53 & 16.00 & 4.93 & 195.65 & 22.63 & 6.20 & 3.60 & 6.90 \\
\hline 11 & NDH-128 & 87.07 & 3.10 & 18.73 & 201.43 & 28.20 & 7.97 & 106.67 & 20.93 & 10.63 & 345.80 & 23.17 & 4.40 & 3.50 & 6.70 \\
\hline 12 & CL-34 & 87.57 & 1.73 & 14.47 & 199.67 & 34.70 & 3.73 & 76.67 & 7.60 & 3.13 & 288.30 & 20.20 & 6.40 & 3.60 & 8.80 \\
\hline 13 & CL-52 & 86.07 & 2.33 & 15.40 & 183.83 & 32.40 & 5.93 & 99.83 & 7.47 & 2.20 & 285.72 & 17.60 & 6.90 & 3.40 & 8.70 \\
\hline 14 & CL-32 & 77.63 & 2.13 & 12.27 & 155.23 & 33.17 & 6.40 & 93.00 & 6.13 & 2.40 & 272.83 & 20.23 & 6.80 & 3.50 & 8.90 \\
\hline 17 & TCP-129 & 55.00 & 2.10 & 12.07 & 166.67 & 25.33 & 4.33 & 61.00 & 9.67 & 3.20 & 240.40 & 22.52 & 5.40 & 3.70 & 7.25 \\
\hline 18 & TCP-161 & 88.20 & 2.13 & 10.83 & 195.87 & 29.67 & 4.93 & 90.00 & 6.67 & 2.43 & 305.00 & 20.10 & 3.60 & 3.90 & 7.55 \\
\hline 19 & CL-54 & 56.63 & 2.00 & 13.00 & 121.33 & 24.67 & 2.97 & 43.77 & 10.00 & 3.00 & 175.30 & 20.33 & 7.20 & 3.20 & 6.80 \\
\hline 20 & RH-407 & 54.83 & 2.10 & 11.83 & 153.33 & 27.33 & 4.33 & 59.30 & 11.20 & 6.03 & 221.60 & 20.17 & 7.00 & 3.90 & 7.10 \\
\hline 21 & NDH-1(Check) & 116.85 & 3.20 & 16.20 & 239.50 & 26.53 & 6.27 & 156.33 & 11.87 & 7.60 & 310.00 & 22.73 & 7.20 & 5.20 & 11.45 \\
\hline \multirow[t]{5}{*}{22} & NDH-2(Check) & 120.70 & 3.13 & 18.60 & 244.90 & 30.13 & 6.85 & 164.00 & 10.65 & 7.73 & 305.77 & 23.23 & 7.37 & 5.80 & 11.30 \\
\hline & Mean & 83.29 & 2.43 & 13.44 & 193.16 & 30.32 & 5.96 & 91.02 & 10.54 & 4.37 & 276.06 & 21.50 & 6.65 & 3.93 & 8.40 \\
\hline & C.V. & 4.76 & 13.78 & 19.61 & 2.59 & 9.09 & 12.47 & 4.30 & 15.44 & 12.18 & 3.52 & 4.56 & 3.05 & 2.65 & 0.62 \\
\hline & S.E. & 2.29 & 0.19 & 1.52 & 2.89 & 1.59 & 0.43 & 2.26 & 0.94 & 0.31 & 5.61 & 0.57 & 0.12 & 0.06 & 0.03 \\
\hline & C.D. $5 \%$ & 6.54 & 0.55 & 4.34 & 8.26 & 4.54 & 1.23 & 6.46 & 2.68 & 0.88 & 16.02 & 1.62 & 0.33 & 0.17 & 0.09 \\
\hline
\end{tabular}


The number of secondary rhizome per plant varied from 3.53 (NDH-162) to 20.93 (NDH128 ) with general mean of 10.54. Seven genotypes viz. NDH-128 (20.63), NDH-79 (16.43), NDH-116 (16.00), NDH-68 (15.33), NDH-74 (14.66), were significant superior for this character than the best check Narendra Haldi-1 (11.87). The highest and lowest number of tertiary rhizome was showed by NDH-128 (10.63) and CL-52 (2.20) respectively. One genotype NDH-128 (10.63) had significantly more number of tertiary rhizome than the best check, Narendra Haldi2 (7.73) for this character. The rhizome yield ( $\mathrm{q} / \mathrm{ha}$ ) ranged from 175.30 (CL-54) to 348.50 (NDH-79) with general mean of 276.06. The genotype NDH -79 (348.50), NDH- 128 (345.80) and NDH-74 (334.80) were best for rhizome yield (q/ha) than the superior checks Narendra Haldi-1 (310.00). The variation in yield and attributing traits of different cultivars grown under different agro-climatic conditions has been also reported by Salimath et al., (2014), Prasath et al., (2016) and Mishra and Singh (2017).

The percent dry matter ranged from 17.60 to 25.77 with general mean 21.50. Genotype NDH-68 (25.77) was significant superior for dry matter (\%) than superior check, Narendra Haldi-2 (23.73). The per cent TSS ranged from 3.60 to 8.30 were with general mean of 6.65; genotypes NDH-161 (8.20), NDH-16 (7.87), NDH-40 (8.20), NDH-68 (8.30), NDH-115 (8.10) were significant superior for this trait than both check. The genotype NDH-2 (5.80) recorded maximum curcumin content while it was lowest in NDH-68 (3.16). Although five genotypes were found significantly superior than population mean but none of the genotypes were superior to either check. Oleoresin content also showed high range of variation among different genotypes. The genotype NDH-2 (11.45) had maximum oleoresin percent while it was lowest in NDH-11(6.45). Although none of the genotypes were found superior than either check ten genotypes were showed significantly superior to population mean. Shanmugasundaram et al., (2001) also reported similar result regarding variability in quality traits among various genotypes.

The variation among all the treatment was highly significant for all the characters studied. The most desirable genotypes for characters other than rhizome yield were NDH-67 for plant height and number of tillers per clump, NDH-68 for number of leaves per shoots, NDH-162 for weight of fresh rhizome, $\mathrm{NDH}-79$ for weight of mother rhizome, NDH79 for number of primary rhizomes per plant, NDH-68 for weight of primary rhizome, NDH-74 for number of secondary rhizome, NDH-128 for tertiary rhizomes per plant, NDH-128 for dry matter per cent and NDH68 for TSS; the genotypes which perform better for various character may be used in breeding programme for incorporation such traits. The three genotypes NDH-79 (348.50 q/ha), NDH-128 (345.80 q/ha) and NDH-74 $(334.80 \mathrm{q} / \mathrm{ha})$ produced significantly more rhizome yield than the best check Narendra Haldi-1 (310 q/ha). Thus, these genotypes may be recommended for commercial cultivation under northern plains of India. They can be further evaluated to identify best genotypes suitable for cultivation at other locations and further used in breeding programmes.

\section{References}

Anonymous (2014). Horticulture database 2014, National Horticulture Board, Gurgaon (Haryana).

Hegde, S., Venkatesh, J. and Chandrappa, H. (1997). Performance of certain promising cultivars of turmeric (Curcuma domestica Val.) under southern dry region of Karnataka. 
Indian Cocoa, Arecanut \& Spice Journal, 19 (1): 8-10.

Mishra, P. and Singh, T. 2017. Evaluation of different turmeric genotypes for yield and yield attributing traits on the basis of mean performance. International Journal of Pure and Applied Bioscience, 5(4): 771-74.

Panse, V.G. and Sukhatme, P.V. (1985). Statistical methods for agricultural workers. ICAR, New Delhi (India).

Prasath, D., Eapen, S.J. and Sasikumar, B. 2016. Performance of turmeric (Curcuma longa) genotypes for yield and root-knot nematode resistance. Indian Journal of Agricultural Sciences, 86(9): 1189-92.

Pruthi, J.S. (1998). Spices and condiments, New Delhi (India), National Book Trust, pp. 125-32.

Rao, C.V., Rivenson, A., Sini, B. and Reddy, B.S. (1995). Chemoprevention as colon Carcino gensis by dietary curcumin, naturally occurring plant phenolic compound. Cancer Research, 55 (2): 259-66.

Salimath, S., Venkatesha, J., Kulkarni, S. and G.R.S. 2014. Evaluation of turmeric (Curcuma longa L.) cultivars for growth and yield in southern dry zone of Karnataka. Advance Research Journal of Crop Improvement, 5(2): 162-65.

Shanmugasundaram, K.A., Thangaraj, T, Azhakiamanavalan, R.S. and Ganga, M. 2001. Evaluation and selection of turmeric (Curcuma longa L.) genotypes. Journal of Spices and Aromatic Crops, 10(1): 33-36.

Srimal, R.C. (1993). Curcumin-A Modern Drug. Indian Spices, 30 (2-3): 21 \& 25.

Srimal, R.C. (1997). Turmeric: a brief review of medicinal properties. Fitoterapia, 68 (6): 483-93.

Srivastava, R., Dikshit, M., Srimal, R.C. and Dhawan, B.N. (1985). Antithrombotic effect of curcumin. Thrombosis Research, 40: 413-17.

\section{How to cite this article:}

Rohit Maurya, V.P. Pandey, Sandeep Yadav, Shubham Yadav and Rahul Kumar Verma. 2018. Evaluation of Turmeric (Curcuma longa L.) Genotypes for Growth, Yield and Quality Traits under Northern Plains of India. Int.J.Curr.Microbiol.App.Sci. 7(05): 2472-2477. doi: https://doi.org/10.20546/ijcmas.2018.705.283 